\title{
Karakteristik Azolla pinnata sebagai Pengganti Bahan Pembawa Pupuk Hayati Padat Bakteri Penambat $\mathrm{N}_{2}$ dan Bakteri Pelarut $\mathrm{P}$
}

\author{
Mieke Rochimi Setiawati1, Pujawati Suryatmana1, dan Amalia Chusnul² \\ ${ }^{1}$ Staff Pengajar Departemen Ilmu Tanah dan Sumberdaya Lahan Fakultas Pertanian \\ Universitas Padjadjaran \\ 2Alumni Program Studi Agroteknologi, Fakultas Pertanian Universitas Padjadjaran \\ Jl. Raya Bandung Sumedang Km 21 Jatinangor \\ Korespondensi: m.setiawati@unpad.ac.id
}

\begin{abstract}
The use of inorganic fertilizers for a long term can reduce soil fertility. One of the alternatives solving this problem is by using solid biofertilizers. Solid biofertilizer requires carrier materials that can support the viability of potential microbial within. Azolla pinnata is one of the carriers that has potential as a substitute for commonly used carrier materials. This study aims to determine the effect of Azolla pinnata and other organic materials with inoculant dosage on viability of bacterial population, N-total, P-total of solid biofertilizer. This research was conducted at Soil Biology Laboratory, Department of Soil Science, Faculty of Agriculture, Padjadjaran University in JanuaryFebruary 2015. The treatments were organic matter (Azolla pinnata, litter compost and peat) with various dosages of bacterial inoculant (20\%, 25\% 30\%). This experiment used the Completely Random Design with factorial pattern. The main observations of the study were analyzed by ANOVA test and continued with Duncan test with 5\% confidence level. The results showed that Azolla pinnata carrier has significantly effect to the increase of $N$-Total and $P$ total of solid biofertilizer. The inoculant dosage of $30 \%$ affects the population increase of Azotobacter sp., and endophytic bacteria, but does not effect to the population of Phosphate Solubilizing Bacteria and Azospirillum sp. Azolla pinnata can be recommended as an alternative carrier that can replace peat and litter compost materials. The results of this study was illustrate Azolla pinnata can be recommended as an alternative carrier for solid biofertilizer that can replace peat and litter compost material with $30 \%$ inoculant dosage.
\end{abstract}

Keywords: Azolla pinnata compost, litter, peat, solid biofertilizer

\section{PENDAHULUAN}

Bahan pembawa merupakan komponen utama dalam pupuk hayati, karena bahan pembawa merupakan habitat sementara mikroba sebelum diaplikasikan ke tanah. Ada berbagai jenis bahan pembawa pupuk hayati yaitu bahan pembawa padat dan cair. Contoh bahan pembawa padat antara lain yaitu kompos, serbuk gergaji, tepung beras, dedak padi, blotong. Contoh bahan pembawa cair yaitu cairan dari limbah tebu (molase), limbah cair pengolahan kedelai pada industri tahu.

Persyaratan bahan yang dapat digunakan sebagai bahan pembawa antara lain harus bisa menjamin keberlangsungan hidup dan efektivitas mikroba yang ada di dalamnya dari gangguan faktor biotik maupun abiotik (Van
Veen, et al., 1997 dalam El-Fattah et al., 2013). Bahan pembawa dapat mempermudah bakteri didalamnya untuk melakukan pertukaran gas terutama oksigen, serta bahan pembawa mempunyai kemampuan tinggi untuk memegang air (Bashan, 1998; Ben Rebah et al.,2002 dalam El-Fattah, et al., 2013).

Azolla pinnata merupakan salah satu paku air yang banyak ditemukan di daerah persawahan yang dapat digunakan sebagai bahan pembawa. Azolla pinnata mudah ditemukan di Indonesia di pesawahan yang memiliki suhu rata-rata lingkungan tumbuh $28^{\circ} \mathrm{C}-35^{\circ} \mathrm{C}$ (Vidhya et al.,2014) sama seperti suhu rata-rata Indonesia. Azolla pinnata dapat dijadikan bahan pembawa karena Azolla 
pinnata dapat menyediakan protein yang mudah didegredasi oleh bakteri (Datta, 2011), serta karena kandungannya yang meliputi: $\mathrm{N}$ 3,08-4,21\%, P 0,16-0,35\%, dan K 1,21-0,09\% (Deptan, 2009).

Laju pertumbuhan Azolla pinnata adalah 0,355-0,390 gram per hari (di laboratorium) dan 0,144-0,890 gram per hari (di lapangan). Pada umumnya pertumbuhan Azolla pinnata maksimum tercapai pada 14-28 hari setelah inokulasi. Batan menyatakan bahwa dengan menginokulasikan $200 \mathrm{~g}$ Azolla pinnata segar per $\mathrm{m}^{2}$ maka setelah 3 minggu, Azolla pinnata akan tumbuh menutupi seluruh permukaan kolam dan dapat dihasilkan 30-40 kg N/ha, berarti sama dengan $100 \mathrm{~kg}$ urea. Pertumbuhan Azolla pinnata juga dinyatakan lebih baik pada musim kemarau (Rosiana dkk, 2013).

Selain Azolla pinnata, gambut merupakan bahan pembawa yang paling sering digunakan dalam produksi pupuk hayati padat. Gambut merupakan hasil dari timbunan bahan organik dalam waktu yang tidak singkat dalam proses pembentukkannya, sehingga kandungan karbon pada tanah gambut sangat tinggi. Fraksi organik tanah gambut jumlahnya di Indonesia lebih dari 95\%, dan kurang dari 5\% adalah fraksi anorganik (Stevenson, 1994; Tan, 1993 dalam Hartatik, dkk., 2000).

Analisis $\mathrm{N}$ total umumnya relatif tinggi namun ketersediaan $\mathrm{N}$ bagi tanaman pada tanah gambut umumnya rendah. Perbandingan kandungan $\mathrm{C}$ dan $\mathrm{N}$ tanah gambut nilainya relatif tinggi, umumnya berkisar 20-45 dan berbanding lurus dengan peningkatan kedalamannya (Radjagukguk, 1997 dalam Hartatik dkk., 2000). Kandungan unsur fosfor (P) pada tanah gambut sebagian besar dijumpai dalam bentuk P-organik, yang selanjutnya akan mengalami proses mineralisasi menjadi P-anorganik oleh jasad mikro. Fraksi P-organik diperkirakan mengandung 2,0\% $\mathrm{P}$ sebagai asam nukleat (Stevenson, 1984, dalam Hartatik dkk., 2000).

Serasah yang dikomposkan juga merupakan bahan pembawa yang umum digunakan sebagai pupuk hayati padat. Serasah adalah guguran daun, batang, cabang, daun, ranting, bunga, dan buah. Serasah memiliki peran penting karena merupakan sumber humus. Serasah Acacia sp. dan Acacia pernesiana memiliki nilai $\mathrm{C} / \mathrm{N}$ yang rendah $<20 \%$ sehingga sangat berpotensi dijadikan sumber bahan organik yang baik (Rindyastuti dan Agung, 2010).

Komponen lain yang penting dalam pupuk hayati adalahmikroba yang bermanfaat. Jenis bakteri yang yang berpotensi untuk digunakan dalam pupuk hayati diantaranya Azotobacter sp., Azospirillum sp., Bakteri endofitik penamat $\mathrm{N}_{2}$ dan Bakteri Pelarut Fosfat. Azotobacter sp. mampu mengubah nitrogen $\left(\mathrm{N}_{2}\right)$ dalam atmosfer menjadi amonia $\left(\mathrm{NH}_{3}\right)$ melalui proses pengikatan nitrogen dimana amonia yang dihasilkan diubah menjadi protein yang dibutuhkan oleh tanaman (Hamastuti et al., 2012).

Azospirillum sp. merupakan bakteri yang dapat berasosiasi dan berinteraksi dengan perakaran, sehingga berperan dalam mengubah morfologi akar, seperti bertambahnya jumlah akar rambut, akar semakin panjang, dan permukaan akar yang semakin luas (Okon 1985, dalam Widawati dan Muharam, 2013). Pal (1998) dalam Ilham dkk. (2014) melaporkan bahwa bakteri pelarut fosfat pada tanah yang dipupuk dengan mengunakan fosfat dapat meningkatkan jumlah dan bobot kering bintil akar serta hasil biji tanaman pada beberapa tanaman yang toleran masam. Bakteri endofitik penambat $\mathrm{N}_{2}$ yang hidup di dalam jaringan tanaman yang fungsinya dapat menambat $\mathrm{N}$ dari dalam jaringan daun, batang dan akar tanaman.

Bahan pembawa Azolla, gambut, dan serasah mengandung unsur makro yang berbeda-beda. Azolla mengandung nitrogen lebih tinggi dari gambut dan serasah, sehingga Azolla dapat memacu pertumbuhan bakteri yang ditambahkan kedalamnya, akan tetapi beberapa bakteri ada yang terhambat aktivitas dan pertumbuhannya bila berlebih kandungan hara di dalam media pertumbuhannya. Dosis inokulan yang mengandung bakteri 
Azotobacter sp., Azospirillum sp., Endofitik dan BPF akan berinteraksi dengan jenis bahan pembawa dalam meningkatkan $\mathrm{N}$ dan $\mathrm{P}$ akibat aktivitas fiksasi $\mathrm{N}_{2}$ oleh Bakteri Penambat $\mathrm{N}$ dan meningkatkan populasi BPF akibat tercukupinya kebutuhan nutrisi terutama unsur $\mathrm{N}$.

\section{METODE PENELITIAN}

Tanaman paku air Azolla pinnata, diperbanyak di dalam kolam Azolla di Kebun Percobaan Fakultas Pertanian Universitas Padjadjaran, pada ketinggian $\pm 700 \mathrm{mdpl}$. Sebagai bahan pembawa azolla dibuat kompos dengan cara didekomposisi secara aerob di dalam tong dekomposer selama 7 hari. Kompos serasah, diperoleh dari pusat pengolahan sampah Kampus Universitas Padjadjaran. Gambut diperoleh dari Rawa Pening Jawa Tengah. Pupuk hayati cair konsorsium diperoleh dari Laboratorium Biologi Tanah yang didalamnya mengandung bakteri yang menguntungkan yaitu Azospirillum sp., Azotobacter sp. bakteri pelarut fosfat dan bakteri endofitik penambat $\mathrm{N}_{2}$.

Metode penelitian dilakukan secara eksperimental dengan menggunakan Rancangan Acak Lengkap (RAL) pola faktorial yang terdiri dari 9 perlakuan yaitu 3 jenis bahan pembawa (kompos Azolla pinnata, kompos serasah, dan gambut) dan 3 dosis inokulan bakteri $(20 \%, 25 \%$, dan $30 \% \mathrm{v} / \mathrm{w})$ dan setiap perlakuan diulang sebanyak 3 kali. Sehingga total perlakuan unit percobaan sebanyak 27 buah.

\section{HASIL DAN PEMBAHASAN}

\subsection{Kandungan Hara Bahan Pembawa}

Bahan pembawa dapat mempengaruhi kualitas pupuk hayati, oleh karenanya perlu dianalisis pada awal sebelum percobaan untuk mengetahui kriterianya dibandingkan standar pupuk hayati padat berdasarkan aturan Permentan No. 70 Tahun 2011. Hasil analisis awal pada berbagai bahan pembawa disajikan pada Tabel 1.
Tabel 1 Hasil Analisis Awal Berbagai Bahan Pembawa Pupuk Hayati Padat

\begin{tabular}{lccc}
\hline & \multicolumn{3}{c}{ Bahan Pembawa } \\
\cline { 2 - 4 } Parameter & Gambut & $\begin{array}{c}\text { Kompos } \\
\text { Serasah }\end{array}$ & $\begin{array}{l}\text { Kompos } \\
\text { Azolla } \\
\text { pinnata }\end{array}$ \\
\hline C-organik (\%) & 4,82 & 26,94 & 39,52 \\
C/N & 4,00 & 26,13 & 9,57 \\
Kadar air (\%) & 34,98 & 26,02 & 15,65 \\
pH & 7,07 & 7,73 & 7,62 \\
$\mathrm{~N}-$ Total (\%) & 1,13 & 0,81 & 4,13 \\
$\mathrm{P}_{2} \mathrm{O}_{5}(\%)$ & 1,95 & 0,30 & 0,53 \\
$\mathrm{~K}_{2} \mathrm{O}(\%)$ & 0,25 & 0,36 & 1,50 \\
\hline Keterangan : Analisis kimia di Laboratorium \\
\multicolumn{4}{c}{ Kesuburan Tanah dan Nutrisi Tanaman, } \\
\multicolumn{4}{c}{ Fakultas Pertanian UNPAD (2014). }
\end{tabular}

Berdasarkan hasil analisis awal kadar Corganik yang paling tinggi adalah kompos Azolla pinnata sebesar 39,52 \%, sedangkan $\mathrm{C} / \mathrm{N}$ yang paling tinggi yaitu kompos serasah sebesar 26,13. Kedua bahan tersebut dapat menjadi sumber energi yang baik bagi mikroba heterotrof. Kadar air pada semua bahan pembawa yang digunakan dalam penelitian ini memenuhi kriteria Permentan No. 70 Tahun 2011 yakni $\leq 35$ \%. Gambut memiliki nilai kadar air paling tinggi, hal ini diduga karena gambut mempunyai kapasitas memegang air maksimum yang tinggi (Hidayanti dan Riwandi, 2011). Selain kadar air, pH pada semua bahan pembawa yang digunakan juga memenuhi kriteria Permentan No. 70 Tahun 2011 yakni 5,0 - 8,0. Berdasarkan hasil analisis nilai $\mathrm{pH}$ pada bahan pembawa netral sampai agak basa. Pada pH 5,5-8.0 bakteri masih dapat melakukan aktivitas dengan baik, meskipun begitu $\mathrm{pH}$ yang optimum untuk aktivitas bakteri adalah sekitar netral (Komarawidjaja, dan Lysiastuti, 2009).

Berdasarkan analisis awal bahan pembawa didapatkan N-Total yang paling tinggi adalah Kompos Azolla pinnata sebesar 4,13\%, Azolla pinnata mempunyai kandungan $\mathrm{N}$-Total paling tinggi karena bersimbiosis dengan Anabaena azollae termasuk ke dalam jenis Sianobakteri, yang mampu menambat $\mathrm{N}_{2}$ dari udara dan mampu menghasilkan 20-100 
kg N ha-1 per musim (Saraswati dan Sumarno, 2009).

Fosfat penting utk pertumbuhan mikroba di dalam media tumbuhnya. Fungsi fosfor adalah menyimpan dan memindahkan energi (ATP, ADP). Fosfor juga berperan dalam membentuk nukleoprotein yang merupakan sebagai penyusun RNA dan DNA (Hardjowigeno, 2007). Kandungan $P$ yang tinggi pada gambut diperkirakan dapat mendukung pembentukan energi di dalam sel mikroba. Hasil analisis didapatkan kompos Azolla pinnata mengandung unsur kalium yang paling tinggi yaitu sebesar $1,50 \%$, kalium berfungsi untuk membentuk dinding sel dan membantu aktivitas enzim.

\subsection{Kadar N-Total Pupuk Hayati Padat}

Nitrogen bagi mikroba berfungsi sebagai pembentuk asam nukleat serta protein yang berperan dalam proses sintesis DNA dan RNA. Hasil analisis menunjukkan bahwa tidak ada pengaruh interaksi antara bahan pembawa dengan dosis inokulan terhadap $\mathrm{N}$ total pupuk hayati. Pengaruh mandiri jenis bahan pembawa mempengaruhi kandungan $\mathrm{N}$ total pupuk hayati padat sedangkan dosis inokulan tidak berpengaruh terhadap peningkatan $\mathrm{N}$ total (Tabel 2).

Tabel 2 N-Total Pupuk Hayati Hayati pada berbagai jenis bahan pembawa dan berbagai dosis inokulan pada akhir masa inkubasi 2 bulan

\begin{tabular}{lc}
\hline \multicolumn{1}{c}{ Perlakuan } & $\begin{array}{c}\text { Kandungan N- } \\
\text { total (\%) }\end{array}$ \\
\hline Bahan Pembawa (A) & $3,26 \mathrm{~b}$ \\
$\mathrm{a}_{1}=$ Kompos Azolla & $0,58 \mathrm{a}$ \\
$\mathrm{a}_{1}=$ Kompos Serasah & $0,96 \mathrm{a}$ \\
$\mathrm{a}_{3}=$ Kompos Gambut & $1,78 \mathrm{a}$ \\
\hline Dosis inokulan bakteri (D) & $1,71 \mathrm{a}$ \\
$\mathrm{d}_{1}=$ Dosis $20 \%$ (v/b) & 1,31 a \\
$\mathrm{d}_{2}=$ Dosis $25 \%$ (v/b) & \\
$\mathrm{d}_{3}=$ Dosis $30 \%$ (v/b) & \\
\hline Keterangan: Nilai rata-rata yang diikuti huruf yang \\
sama tidak berbeda nyata berdasarkan \\
Uji Duncan pada taraf $5 \%$.
\end{tabular}

Bahan pembawa Azolla pinnata sangat berpengaruh nyata terhadap peningkatan kandungan $\mathrm{N}$-total yaitu sebesar 3,26 \% $\mathrm{N}$. Hal ini sejalan dengan analisis awal bahwa bahan pembawa kompos Azolla pinnata mengandung N-Total yang tinggi jika diban-dingkan dengan bahan pembawa lainnya, hal ini dikarenakan Azolla pinnata mempunyai kemampuan simbiosis mutualisme dengan Anabaena azollae penambat $\mathrm{N}_{2}$ sehingga Azolla pinnata menjadi bahan organik yang kandungan N-totalnya tinggi. Simbiosis antara tanaman paku air Azolla pinnata dengan Anabaena tedapat pada pangkal daun (Winaya, dkk., 2010).

Respon N-Total yang diperoleh dari berbagai dosis inokulan menunjukkan hasil yang tidak berbeda. Diduga bakteri penambat $\mathrm{N}$ yang diinokulasikan tidak berkembang tetapi dalam keadaan dorman dengan adanya kandungan $\mathrm{N}$ yang tinggi sehingga tidak menambah $\mathrm{N}$ total pupuk hayati. Ada kecenderungan terjadi penurunan N-Total pada pupuk hayati padat di setiap kenaikan dosis inokulan pupuk hayati.

\subsection{Kandungan P Total Pupuk Hayati Padat}

Unsur $\mathrm{P}$ dalam aktivitas mikroba berperan dalam pembelahan sel, penyimpanan, dan pemindahan energi, serta dalam pembentukan nukleoprotein sebagai penyusun RNA, dan DNA (Hardjowigeno, 2007). Berdasarkan hasil analisis menunjukkan bahwa tidak terdapat interaksi antara berbagai jenis bahan pembawa dengan dosis inokulan bakteri terhadap P-total. Hasil pengamatan P-total dapat dilihat pada Tabel 3.

Berdasarkan hasil analisis statistik, perlakuan jenis bahan pembawa memberikan pengaruh nyata terhadap P-total, sedangkan perlakuan dosis inokulan tidak memberikan pengaruh nyata terhadap P-total. Gambut memberikan pengaruh nyata yang paling tinggi sebesar 0,93\%, dilanjutkan dengan Kompos Azolla pinnata sebesar 0,48 \%, dan Kompos Serasah 0,19 \%. Berdasarkan analisis awal sebelum perlakuan bahan 
pembawa P-Total yang paling tinggi adalah gambut sehingga mempengaruhi kandungan $\mathrm{P}$ total pupuk hayati yang dihasilkannya. $\mathrm{P}$ tidak terlarut di dalam bahan dapat dilarutkan oleh bakteri pelarut fosfat menjadi bentuk yang tersedia bagi mikroba di dalam bahan pembawa. Selain bakteri penambat N, mikroba pelarut fosfat juga membutuhkan fosfat dalam bentuk tersedia untuk pertumbuhannya (Ginting dkk., 2012) sehingga ada kecenderungan P-total di dalam bahan pembawa pada analisis akhir akan menurun.

Tabel 3 P-total pupuk hayati pada berbagai jenis bahan pembawa dan dosis inokulan pada akhir masa inkubasi 2 bulan

\begin{tabular}{lc}
\hline \multicolumn{1}{c}{ Perlakuan } & P-total (\%) \\
\hline Bahan Pembawa (A) & $0,48 \mathrm{~b}$ \\
$\mathrm{a}_{1}=$ Kompos Azolla & $0,19 \mathrm{a}$ \\
$\mathrm{a}_{1}=$ Kompos Serasah & $0,93 \mathrm{c}$ \\
$\mathrm{a}_{3}=$ Kompos Gambut & $0,52 \mathrm{a}$ \\
\hline Dosis inokulan bakteri (D) & \\
$\mathrm{d}_{1}=$ Dosis $20 \%(\mathrm{v} / \mathrm{b})$ & $0,52 \mathrm{a}$ \\
$\mathrm{d}_{2}=$ Dosis $25 \%(\mathrm{v} / \mathrm{b})$ & $0,56 \mathrm{a}$ \\
$\mathrm{d}_{3}=$ Dosis $30 \%(\mathrm{v} / \mathrm{b})$ & Kilai rata-rata yang diikuti huruf yang \\
\hline Keterangan : & sama tidak berbeda nyata berdasarkan \\
\multicolumn{2}{l}{ Uji Duncan pada taraf $5 \%}$.
\end{tabular}

Berdasarkan Tabel 3, semua dosis inokulan yang diberikan tidak memberikan pengaruh nyata terhadap kandungan $\mathrm{P}$ total pupuk hayati, akan tetapi pemberian dosis inokulan $30 \%$ memperlihatkan tendensi meningkatkan $\mathrm{P}$ total dibandingkan dosis inokulan $20 \%$ dan $25 \%$.

Fosfor di dalam bahan pembawa tidak dipengaruhi oleh inokulan yang diberikan karena bakteri pelarut fosfat yang diinokulasikan hanya mengubah ketersediaan $\mathrm{P}$ di dalam media walaupun setelah bakteri tersebut mati dan termineralisasi dapat menyumbangkan $\mathrm{P}$ organik ke dalam media dalam jumlah yang kecil.

\subsection{Total Populasi Bakteri pada Pupuk Hayati Padat}

Berdasarkan pengamatan pertumbuhan bakteri dari awal inokulasi hingga akhir inkubasi selama 2 bulan didapatkan bahwa bakteri memiliki waktu yang berbeda-beda untuk mencapai setiap fasenya. Terutama fase adaptasi dimana pada fase ini bakteri mulai menyesuaikan diri dengan lingkungan baru berupa bahan pembawa.

Berdasarkan hasil analisis statistik didapatkan bahwa di minggu terakhir pada pengamatan bahan pembawa, gambut dapat meningkatkan semua populasi bakteri kecuali populasi BPF. Pada pemberian dosis inokulan yang berbeda, dosis inokulan 25\% dan 30\% dapat meningkatkan populasi bakteri Azotobacter dan bakteri endofitik penambat $\mathrm{N}_{2}$.

Tabel 4 Pengaruh jenis bahan pembawa dan dosis inokulan terhadap populasi bakteri pada akhir masa inkubasi

\begin{tabular}{|c|c|c|c|c|}
\hline \multirow[b]{2}{*}{ Perlakuan } & \multicolumn{4}{|c|}{ Populasi bakteri(cfu/g) pada minggu ke-8 } \\
\hline & $\begin{array}{c}\text { Azotobacter } \\
\left(10^{9}\right)\end{array}$ & $\begin{array}{l}\text { BPF } \\
\left(10^{9}\right)\end{array}$ & $\begin{array}{l}\text { Endofit } \\
\left(10^{11}\right)\end{array}$ & $\begin{array}{c}\text { Azospirillum } \\
\left(10^{10}\right)\end{array}$ \\
\hline \multicolumn{5}{|l|}{ Bahan pembawa (A): } \\
\hline$a_{1}=$ kompos azolla & $1.54 \mathrm{a}$ & $1,29 \mathrm{a}$ & $1,54 \mathrm{a}$ & $1,01 \mathrm{a}$ \\
\hline $\mathrm{a}_{2}=$ kompos serasah & $1.47 \mathrm{a}$ & $1,48 \mathrm{a}$ & $1,47 \mathrm{a}$ & $1,49 \mathrm{a}$ \\
\hline $\mathrm{a}_{3}=$ kompos gambut & $2.97 \mathrm{~b}$ & $1,48 \mathrm{a}$ & $2,97 \mathrm{~b}$ & $3,76 \mathrm{~b}$ \\
\hline \multicolumn{5}{|l|}{ Dosis inokulan awal (D): } \\
\hline $\mathrm{d}_{1}=20 \%$ inokulan bakteri $(\mathrm{v} / \mathrm{b})$ & $1.48 \mathrm{a}$ & $1,44 \mathrm{a}$ & $1,48 \mathrm{a}$ & $1,63 \mathrm{a}$ \\
\hline $\mathrm{d}_{2}=25 \%$ inokulan bakteri $(\mathrm{v} / \mathrm{b})$ & $2.06 \mathrm{ab}$ & $1,37 \mathrm{a}$ & $2,06 \mathrm{ab}$ & $2,29 \mathrm{a}$ \\
\hline $\mathrm{d}_{3}=30 \%$ inokulan bakteri $(\mathrm{v} / \mathrm{b})$ & $2.43 \mathrm{~b}$ & $1,43 \mathrm{a}$ & $2,43 \mathrm{~b}$ & $2,34 \mathrm{a}$ \\
\hline
\end{tabular}


Setelah akhir masa inkubasi 8 minggu terlihat dengan pemberian inokulan dengan dosis $30 \%$ dapat meningkatkan populasi Azotobacter sp. dan Endofitik penambat $\mathrm{N}_{2}$ dibandingkan pemberian dosis inokulan $20 \%$. Berdasarkan hasil analisis statistik didapatkan bahwa pada akhir inkubasi, didapatkan jumlah populasi bakteri berkisar $10^{9}-10^{11} \mathrm{cfu} / \mathrm{g}$ bahan pembawa yang memenuhi standar Permentan No 70 tahun 2011 bahwa populasi minimal pupuk hayati padat berbentuk serbuk sebesar $10^{7} \mathrm{cfu} / \mathrm{g}$. Hal ini dapat menjadi rekomendasi bahwa kompos Azolla dapat digunakan sebagai pupuk hayati padat dengan dapat menjaga viabilitas mikroba di dalamnya sehingga viabilitasnya sesuai standar Permentan No 70 tahun 2011 yaitu lebih besar dari $10^{7} \mathrm{cfu} / \mathrm{g}$ media.

\section{KESIMPULAN}

Hasil penelitian menunjukkan bahwa tidak terdapat interaksi antara bahan pembawa dengan dosis inokulan terhadap peningkatan kandungan N-total, P-total dan populasi mikroba di dalam pupuk hayati sampai akhir inkubasi.

Setelah masa inkubasi selama 2 bulan, bahan pembawa Azolla pinnata meningkatkan kandungan N-Total dan kandungan P-Total pupuk hayati padat. Dosis inokulan $30 \%$ dapat meningkatkan populasi bakteri Azotobacter sp., dan bakteri Endofitik, tetapi tidak meningkatkan populasi Bakteri Pelarut Fosfat dan Azospirillum sp. Pada akhir masa inkubasi semua formula memiliki populasi sebesar $10^{9}$ hingga $10^{11} \mathrm{cfu} / \mathrm{g}$, sesuai standar Permentan nomor 70 tahun 2011 sehingga Azolla pinnata dapat direkomendasikan sebagai alternatif bahan pembawa yang dapat menggantikan bahan pembawa gambut maupun kompos serasah.

\section{DAFTAR PUSTAKA}

Datta, S.N. 2011. Culture of Azolla and Its Efficacy in Diet of Labeo
Rohita.https://www.researchgate.net Lpublication/229143844 Culture of Azolla and its efficacy in diet of Lab eo rohita

Deptan. 2009. Turi mini dan Azolla pinnata dapat Mensubstitusi sebagian Pupuk Nitrogen.

http://pustaka.litbang.deptan.go.id/p ublikasi/wr313096.p df.

El-Fattah, D.A.A, Wedad E. Eweda, Mona S. Zayed, Mosaad K. Hassanein. 2013. Effetct of Carrier Materials, Sterilization Method and Storage Temperature on Survival and Biological Activities of Azotobacter chroococcum Inoculant. http://www.sciencedirect. com/science/article Lpii/S0570178313000237.

Ginting, R.C.B., Rasti Saraswati, dan Edi Husain. 2012. Mikroorganisme pelarut fosfat. Dalam Suriadikarta, D.A. dan Simanungkalit, R.D.M. (eds). Pupuk Organik.

litbang.pertanian.go.id/ind/dokument asi/lainnya/07mikroorganisme $\% 20 \mathrm{p}$ elarut $\% 20$ fosfat.pdf

Hamastuti, H., Elysa, D.O, S.R Juliastuti, dan Nuniek, H. 2012. Peran mikroorganisme azotobacter chroococcum, pseudomonas fluorescens, dan aspergillus niger pada pembuatan kompos limbah sludge industri pengolahan susu. Jurnal Teknik POMITS. Vol 1(1): 1-5.

Hardjowigeno, S. 2007. Ilmu Tanah. Jakarta: Akademika Pressindo.

Hartatik, Subiksa, Ai Dariah. 2012 Sifat Kimia dan Sifat Fisik Tanah Gambut.balittanah.litbang. pertanian.go.id/ind/dokumentasi/lai nnya/wiwik hartatik.pdf

Hidayanti, N dan Riwandi. 2011. Laju subsiden pada sistem drainase dan pengapurantanah gambut fibrik dengan pertanaman jagung. Prosiding Seminar Nasional Budidaya Pertanian; Urgensi dan Strategi Pengendalian Alih Fungsi Lahan 
Pertanian. Bengkulu 7 Juli 2011. Hal 44-59.

Ilham, I.B.G. Darmayasa, dan Retno K. 2014. Isolasi dan Identifikasi Bakteri Pelarut Fosfat Potensial Pada Tanah Konvensional dan Tanah Organik. Simbiosis Journal of Biological Science. Vol II (1): 173-183.

Komarawidjaja, W. dan Lysiastuti, L. 2009. Status konsorsium mikroba lokal pendegradasi minyak. Jurnal Teknik Lingkungan, Vol. 10 (3). Hal: 347-354.

Rindyastuti, R dan Darmayanti, A.S. 2010. Komposisi Kimia dan Estimasi Proses Dekomposisi Serasah 3 Spesies Familia Fabaceae di Kebun Raya Puwodadi. Seminar Nasional Biologi 2010.http://www.krpurwodadi.lipi.g o.id/publikasi/komposisi kimia. pdf

Rosiana, F., Tien. T, Y. Yuwariah, M. Arifin, dan T. Simarmata. 2013. Aplikasi kombinasi kompos jerami, kompos azolla pinnatadan pupuk hayati untuk meningkatkan jumlah populasi bakteri penambat nitrogen dan produktivitas tanaman padi berbasis IPAT-BO. Agrovigor. Vol 6(1). Hal: 16 $-22$.

http://pertanian.trunojoyo.ac.id/wpcontent/uploads/2014/05/2.Agrovigor-Maret-2013-Vol-6-No-1Aplikasi-Kombinasi-Kompos-JeramiFerike-Rosian-dkk-.pdf.
Saraswati, R dan Sumarno. 2008. Pemanfaatan Mikroba Penyubur Tanah Sebagai Komponen Teknologi Pertanian. Jurnal iptek tanaman pangan Vol 3 (1). Hal: 41-58.

Vidhya. K., Uthayakumar. V, Muthukumar.S, Munirasu. S and Ramasubramanian. V. 2014. The effects of mixed algal diets on population growth, egg productivity and nutritional profiles in cyclopoid copepods (Thermocyclops hyalinus and Mesocyclops aspericornis). The Journal of Basic \& Applied Zoology. Vol 67. Pp. 58-65.

http://www.sciencedirect.com/scienc e/article/pii/S2090989614000174

Widawati dan Muharram. 2012. Uji Laboratorium Azospirillum sp. yang diisolasi dari Beberapa Ekosistem.http://hortikultura.litbang. pertanian.go.id/jurnal.pdf/223/8Muharam Azopirillum.pdf.

Winaya, A., Maftuchah, Agus, Z. 2010. Tanaman air Azolla sp. sebagai imbuhan pakan dan pengaruhnya terhadap tampilan produksi ayam broiler strain hubbard. Jurnal Sain Peternakan Indonesia Vol. 5 (1). Hal: 1-12. 